\title{
Absence of xenotropic murine leukaemia virus-related virus in Danish patients with multiple sclerosis
}

\author{
Romana Maric ${ }^{1}$, Finn S Pedersen², Anders Kjeldbjerg ${ }^{2}$, Anné Moeller-Larsen ${ }^{1}$, Shervin Bahrami ${ }^{2}$, Tomasz Brudek , \\ Thor Petersen ${ }^{3}$, Tove Christensen ${ }^{1 *}$
}

From 15th International Conference on Human Retroviruses: HTLV and Related Viruses

Leuven and Gembloux, Belgium. 5-8 June 2011

\section{Background}

Detection of a novel Gammaretrovirus, Xenotropic Murine leukaemia virus-Related Virus (XMRV) has been reported in peripheral blood mononuclear cells of patients with chronic fatigue syndrome, and in prostate cancer tissue. As Multiple Sclerosis (MS) is a disease with retroviral association (human endogenous retroviruses (HERVs)), we investigated whether XMRV could be contributing to MS aetiology by testing a well defined cohort of Danish MS patients for the presence of XMRV sequences.

\section{Materials and methods}

We have analysed DNA samples isolated from peripheral blood mononuclear cells (PBMCs) from 50 Danish patients with clinically well-characterized MS for evidence of the presence of XMRV gag or env sequences by PCR, using concomitant amplification of the cellular GAPDH gene as control.

\section{Results}

In this study, which included relevant positive and negative isolation controls and PCR controls, we failed to detect XMRV sequences in PBMCs from Danish MS patients.

\section{Conclusions}

There is no apparent association between XMRV infection and MS in Denmark.

\footnotetext{
* Correspondence: tc@microbiology.au.dk

'Department of Medical Microbiology and Immunology, Aarhus University, Aarhus, DK-8000 C, Denmark

Full list of author information is available at the end of the article
}

\section{Author details}

'Department of Medical Microbiology and Immunology, Aarhus University, Aarhus, DK-8000 C, Denmark. ²Department of Molecular Biology, Aarhus University, Aarhus, DK-8000 C, Denmark. ${ }^{3}$ Department of Neurology, Aarhus University Hospital, Aarhus, DK-8000 C, Denmark.

Published: 6 June 2011

doi:10.1186/1742-4690-8-S1-A213

Cite this article as: Maric et al: Absence of xenotropic murine leukaemia virus-related virus in Danish patients with multiple sclerosis. Retrovirology 2011 8(Suppl 1):A213.
Submit your next manuscript to BioMed Central and take full advantage of:

- Convenient online submission

- Thorough peer review

- No space constraints or color figure charges

- Immediate publication on acceptance

- Inclusion in PubMed, CAS, Scopus and Google Scholar

- Research which is freely available for redistribution

Submit your manuscript at www.biomedcentral.com/submit

\section{() Biomed Central}

\section{Biomed Central}

